\title{
Experimental and numerical studies on the belltower of Santa Justa y Rufina (Orihuela-Spain)
}

\author{
Salvador Ivorra \\ Universidad de Alicante. Departamento de Ingeniería de la Construcción, OO.PP. e I.U. Alicante. Spain \\ Francisco Pallarés \\ Polytechnic University of Valencia. Departamento de Física Aplicada,Valencia, Spain \\ José Miguel Adam \\ Polytechnic University of Valencia. ICICTH, Valencia, Spain
}

\begin{abstract}
The bell-tower of Santa Justa y Rufina is located in the historical city of Orihuela (AlicanteSpain). Its construction dates from the XV century, having suffered several changes later. The monumental group was declared National Monument by the Spanish government in 1971. For the study of the structural behaviour of the tower it becomes necessary to know its dynamic response influenced by two important aspects: a) the construction is located in a high seismic risk area, and b) the tower is endowed with six bells that rotate on their axis according to the Spanish characteristic system at a speed between $20 \mathrm{cycles} / \mathrm{min}$ and $40 \mathrm{cy}-$ cles/min. With the purpose of studying its dynamic response a monitoring program has been carried out using accelerometers with the aim of determining the bending and torsional natural frequencies of the tower as well as approaching the value of the structural damping ratio of the construction. Once the experimental results were analyzed, a numerical model of the tower was carried out. This model has been calibrated using the experimental results to assess the seismic vulnerability of the structure to earthquakes that currently the Spanish Standard states for this area, as well as to evaluate the effect of the swinging of the bells after the future restoration planned. The overall elastic modulus and joint rigidity of the tower and the nave of the church have been considered as control parameters. A foundation of $1.5 \mathrm{~m}$ height was considered; the connection between the tower and the foundation has not been considered rigid.
\end{abstract}

\section{INTRODUCTION}

\subsection{General}

This paper presents an initial work made on the belltower of Santa Justa y Rufina church in Orihuela (Alicante-Spain). This structure is a gothic belfry made in XV century that possesses five bells. Some restoration works are planned on these bells and it is necessary to know de dynamic characteristics of the tower to discard future problems originated by a possible dynamic interaction between the natural frequencies of the tower and the horizontal forces introduced by the bells on the tower.

\subsection{Geometric description}

The belltower has tree main bodies typical from the gothic belltowers built in the XV century: base, bell room and crown -Fig. 1 and 2-. The main body possesses a square section with $8.8 \mathrm{~m}$ long; inside there is a stairway that gives access to the body of bells. All the structure is made in masonry, arranging brick masonry with ashlars, maintaining a constant thickness of $1.5 \mathrm{~m}$ along the whole first body of the tower. The total height is $25.5 \mathrm{~m}$. The bell room reaches the height of $35.5 \mathrm{~m}$ with $1.0 \mathrm{~m}$ wall thick- ness. Seven windows are inside this body (in each wall) to accommodate the bells with approximately $5.5 \mathrm{~m} 2$ each window.

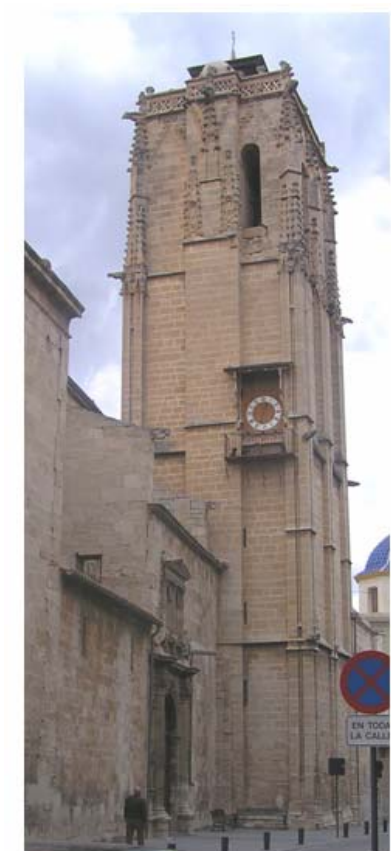

(a)

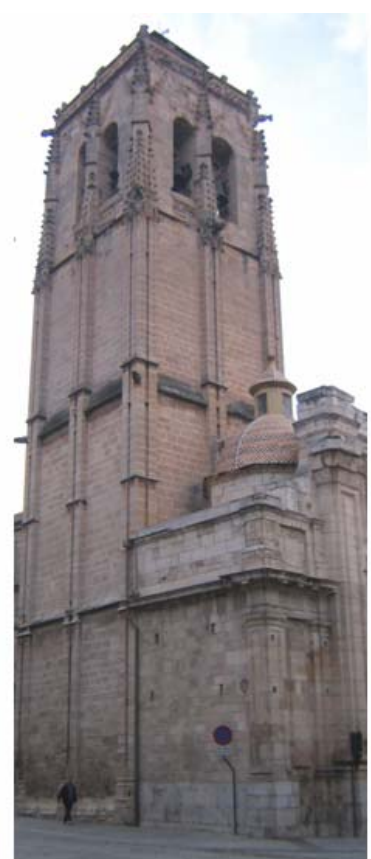

(b)
Figure 1. (a) West façade. (b) East façade 
The tower has a rigid joint with the lateral walls of the main body of the church. This joint can be observed in the west, south and east sides of the tower. The joint in the west wall of the nave reaches the height of $18 \mathrm{~m}$, although the joint of the east wall reaches $9 \mathrm{~m}$ high. (Figure 3 )

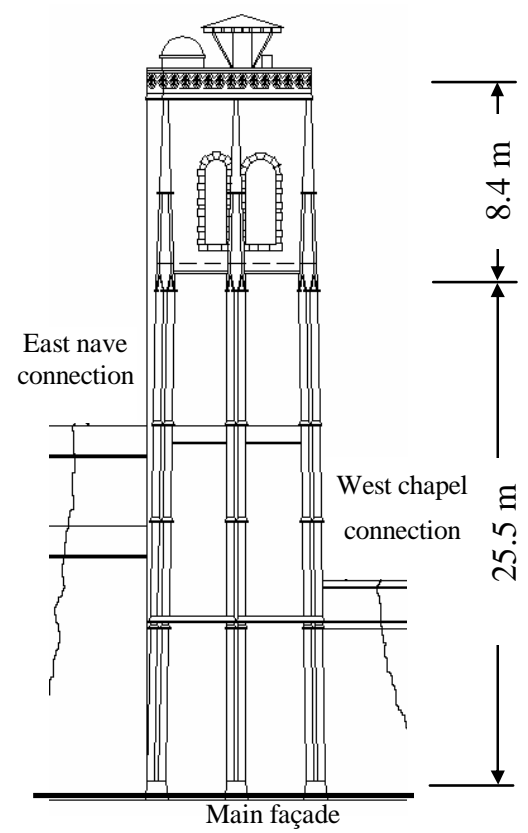

Figure 2. (a) General diagram of the tower. Architectural plan.

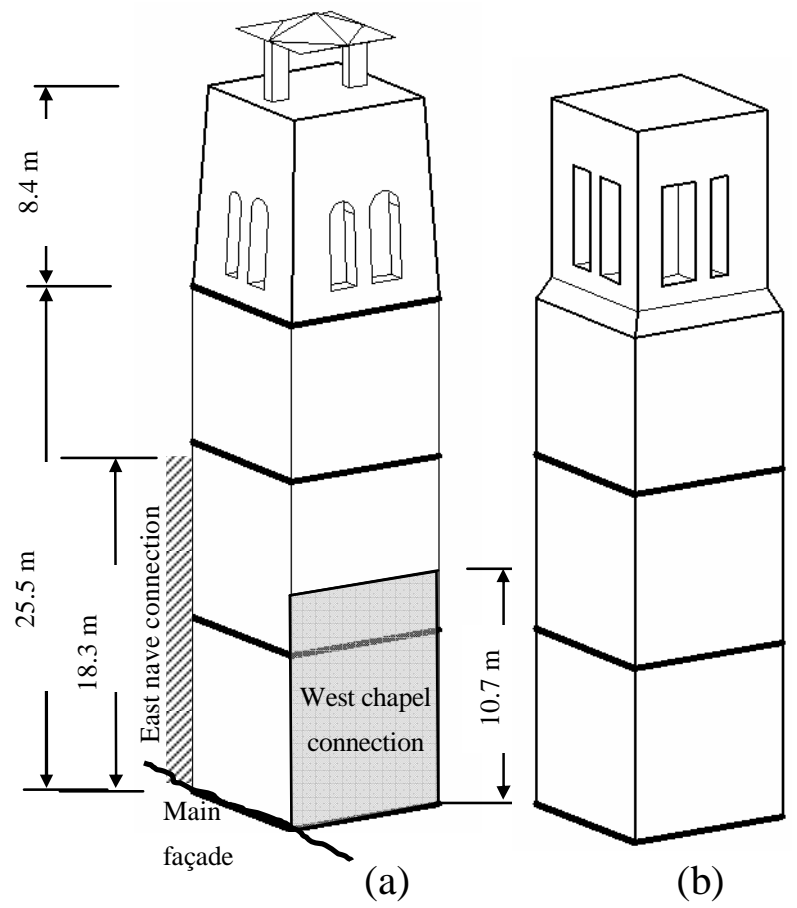

Figure 3. (a) Simplified model. (b) Model to simulate with FEM.

\section{DYNAMIC TEST}

Several dynamic tests have been performed on the belltower to know the mechanical parameters, vibration modes (bending and torsion) and structural damping. All of them are based on the registration of ambient vibrations at different heights and directions. Only bending and torsional vibrations are registered due to the high longitudinal stiffness.

The works of Bachmann (1997) and Casolo (1998) fix the main torsional and bending frequencies between 0.9 and $2 \mathrm{~Hz}$ for slender towers, and analogous results are obtained by Gentile (2007). The work made by Ivorra (2006) in a similar belltower allows evaluating frequencies and the experimental procedure.

From equation (1) proposed in NCSE-02 (2002), belltower frequencies can be estimated:

$$
\begin{aligned}
& \omega_{1}=\frac{\sqrt{L}}{0.06 \cdot H \cdot \sqrt{\frac{H}{2 \cdot L+H}}} ; \\
& \omega_{2}=3 \cdot \omega_{1} ; \\
& \omega_{3}=5 \cdot \omega_{1} ;
\end{aligned}
$$

where: $\mathrm{L}$ is the plan dimension along the vibration direction and $\mathrm{H}$ is the height.

So, it is expected to register a first frequency round $1.7 \mathrm{~Hz}$ or higher, since the stiffness is higher due to the contact with the church.

In order to make the dynamic experimental measurements, eight piezoelectric seismic accelerometers have been placed at the height of the bell room as shown in Fig. 4. The working range of these accelerometers varies between 0.5 and $2000 \mathrm{~Hz}$, with a conversion factor equal to $1000 \mathrm{mV} / \mathrm{g}$. According to the arrangement commented, belltower vibrations in the E-W and N-S directions could be determined. The dynamic data obtained from the ambient vibration have been registered by a Kyowa PCD-320 equipment with a sample rate of $200 \mathrm{~Hz}$. Fig. 5 shows the acquisition system and some accelerometers. Temporary acceleration movements have been analysed with DAS-100a Kyowa software to obtain frequency results. 


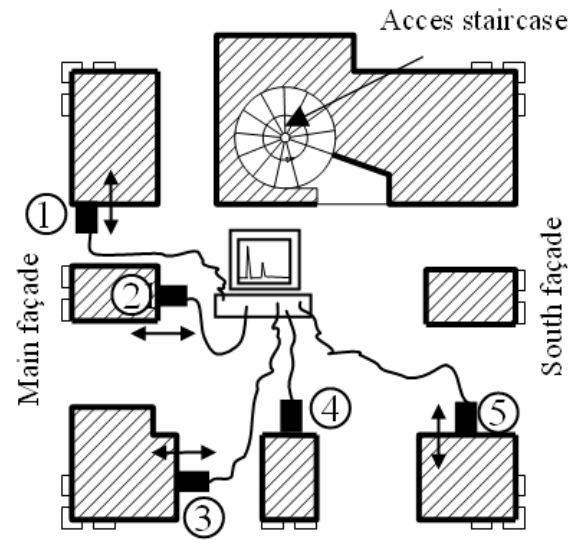

West façade

(a)

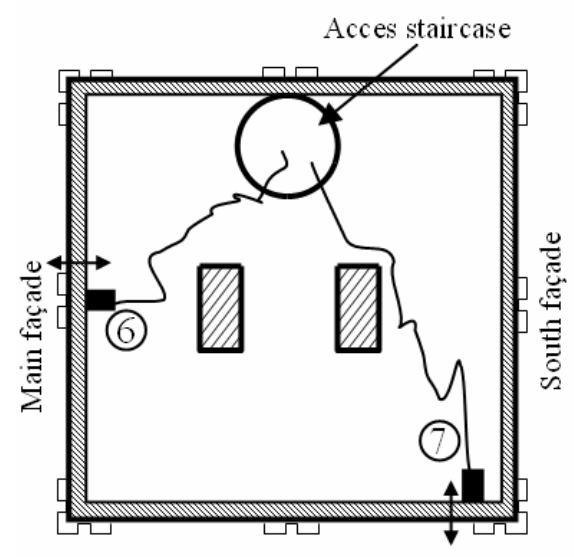

West façade

(b)

Figure 4. Accelerometers arrangement in the belltower.

(a) $27 \mathrm{~m}$ height section. (b) Top of the tower.

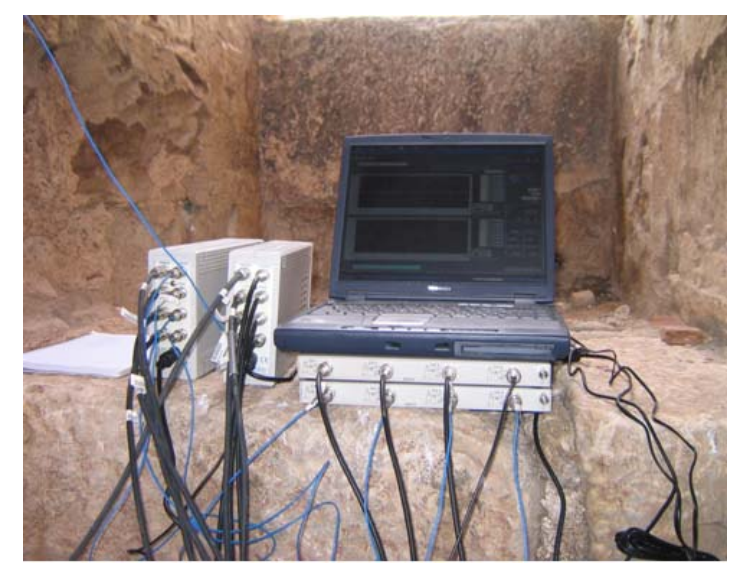

(a)

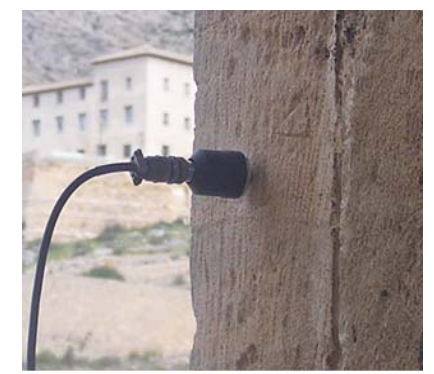

(b)

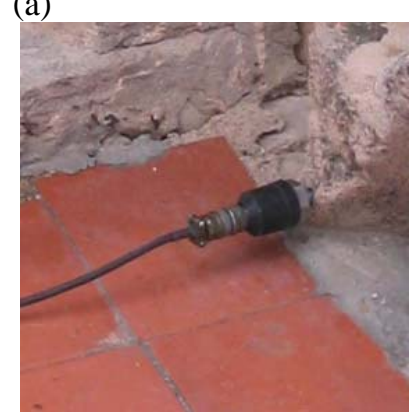

(c)
Figure 5. Accelerometers arrangement in the belltower. (a) Acquisition system. (b) Accelerometer $n^{\circ} 3$. (c) Accelerometer $n^{\circ} 7$
Power spectra responses in E-W and N-S directions have been obtained from ambient vibrations, so the modal parameters can be concluded as shown in Table 1 and figure 6 .

Table 1: Belltower natural frequencies.

\begin{tabular}{cccc}
\hline Accelerometer & Direction & $\begin{array}{c}\text { Frequency } \\
(\mathrm{Hz})\end{array}$ & Mode classification \\
\hline $2-3-6$ & $\mathrm{~N}-\mathrm{S}$ & 2.24 & Bending \\
\hline $1-4-5-7$ & $\mathrm{E}-\mathrm{W}$ & 2.15 & Bending \\
\hline $1-3-5-7$ & - & 5.95 & Torsion \\
\hline
\end{tabular}

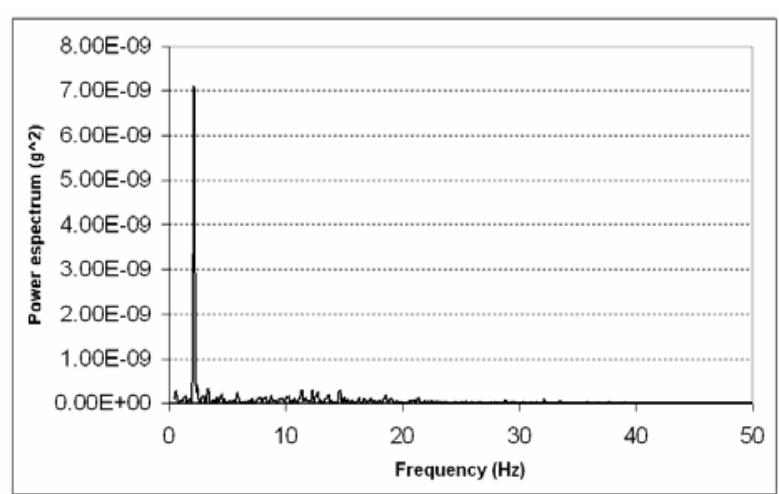

(a)

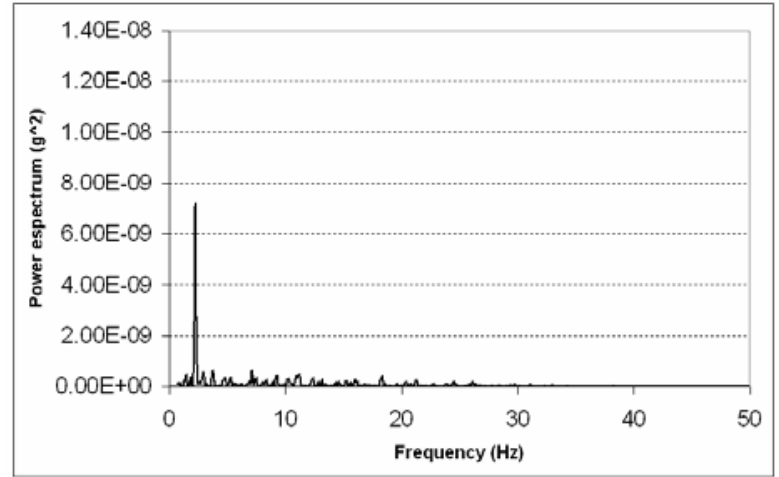

(b)

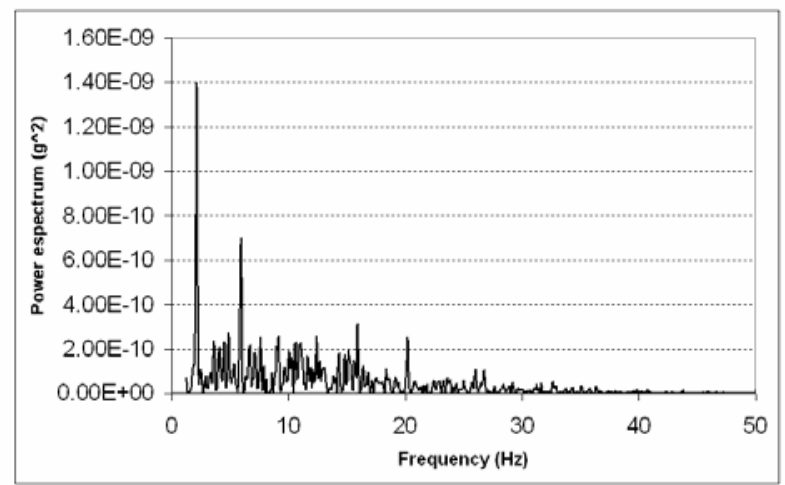

(c)

Figure 6. Power spectrum of obtained signal. (a) Accelerometer 6: $2.15 \mathrm{~Hz}$. (b) Accelerometer 4: $2.24 \mathrm{~Hz}$. (c) Accelerometer 5: $2.24 \mathrm{~Hz}, 5.95 \mathrm{~Hz}$.

The structural damping ratio is obtained from the results in Ivorra (2006), since the structures involved have very similar characteristics and analogous period of construction. The average damping ratio used 
in the present work for the masonry belltower is 0.0159 .

\section{BELL FORCES}

On the windows of the belfry five bells are located (see figure 8). These bells swing according to the Spanish system: A counterweight provides a high level of balance (see figure 7) and the bells, directly anchored on the tower windows, rotate continuously in the same direction.

The characteristics of these bells have been determined according to the works of Heyman\&Therefall (1976), Ivorra\&Llop (2002) and Ivorra et al. (2005); they are presented in table 2.

Table 2: Characteristics of the bells of the tower

\begin{tabular}{lcccccc}
\hline \multicolumn{1}{c}{ Bell } & $\begin{array}{c}\text { Unbal- } \\
\text { ance }^{1} \\
(\mathrm{~m})\end{array}$ & $\begin{array}{c}\text { Bronze } \\
\text { weight } \\
(\mathrm{N})\end{array}$ & $\begin{array}{c}\text { Total } \\
\text { weight } \\
(\mathrm{N})\end{array}$ & $\begin{array}{c}\text { Swing } \\
\text { velocity } \\
(\mathrm{Hz})\end{array}$ & $(2)$ & $(3)$ \\
\hline $\begin{array}{l}\text { (1) Maria } \\
\text { Antonia } \\
\text { (2) San }\end{array}$ & 0.08 & 1310 & 2096 & 0.67 & 0.65 & 1.81 \\
$\begin{array}{l}\text { Jose } \\
\text { (3) N.S. }\end{array}$ & 0.07 & 2350 & 3760 & 0.57 & 0.54 & 1.41 \\
$\begin{array}{l}\text { Guadalupe } \\
\text { (4) N.Sra. }\end{array}$ & 0.07 & 4360 & 6976 & 0.58 & 0.58 & 1.71 \\
$\begin{array}{l}\text { Rosario } \\
\text { (5) Stas }\end{array}$ & 0.09 & 7500 & 12000 & 0.42 & 0.7 & 2.18 \\
$\begin{array}{l}\text { Justa y } \\
\text { Rufina }\end{array}$ & 0.08 & 12720 & 20352 & 0.30 & 0.64 & 1.92 \\
\hline
\end{tabular}

${ }^{1}$ Distance between centre of rotation and centre of gravity.

${ }^{2}$ Maximum horizontal force divided by total weight

${ }^{3}$ Maximum vertical force divided by total weight

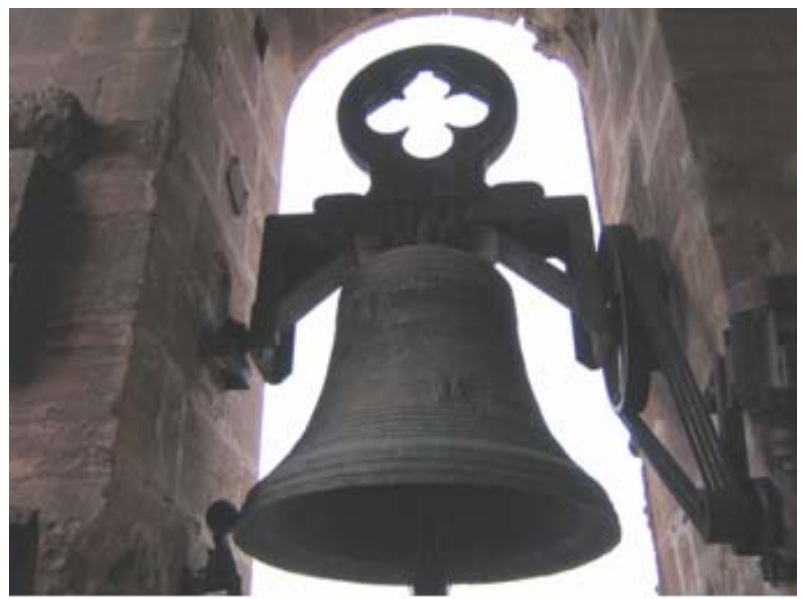

Figure7. Bell Santas Justa y Rufina. Big rotating bell.

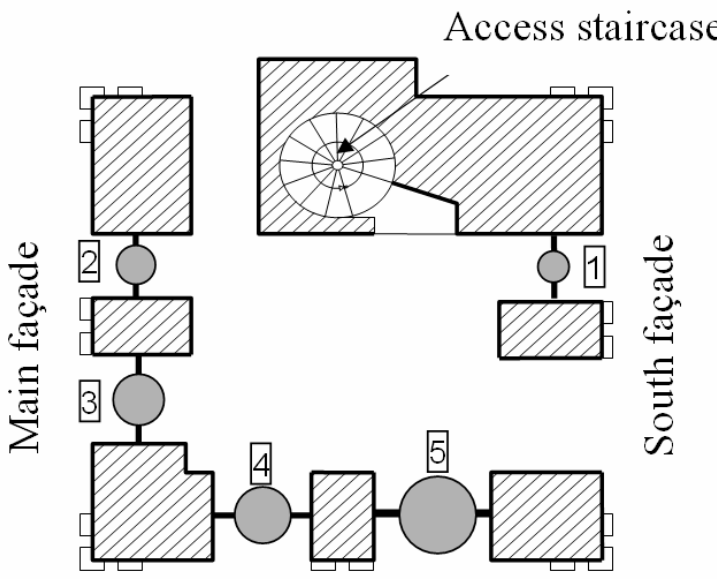

Figure 8. Bell disposition on the tower.

\section{3-D FEM}

As a first approximation, a simplified 5 degrees of freedom model has been used to know the belltower response to bell forces. A more refined numerical model was done using the commercial software SAP2000 ${ }^{\mathrm{TM}}$. 8-node-hexaedral finite elements have been used to mesh the model with three degrees of freedom per node. An iterative process has been performed to fit, through a modal analysis, the fundamental frequencies of the initial model and those registered from the real model. The results of this stage are shown in Fig. 10 (vibration modes) and Table 3.

The main assumptions for the numerical model are:

- Constant average material density $18 \mathrm{kN} / \mathrm{m} 3$, as stated in the Spanish standard NBE AE -88 applied to masonry structures with solid bricks. In the beam models it is supposed to be uniformly distributed.

- The Poisson's ratio of the masonry was held constant and equal to 0.15 .

- Linear and elastic mechanical behaviour during the calibration stage and modal analysis.

- Displacements restrained in the W-E direction on the East wall up to the height of $18.2 \mathrm{~m}$ and on the West wall up to the height of $10.3 \mathrm{~m}$ because of the contact with the lateral wall of the nave. Equally, displacements in the N-S direction are restrained in the South wall for the same reason. These constraints can be observed in Figure 9.

- The interaction between soil and structure is considered modelling the soil by a $17.7 \times 17.7 \times 8.25$ meters 3D model. The elastic modulus and Poisson's ratio are adjusted through an iterative process to get appropriate values for the whole model in accordance with the experimental values. 
Fig. 9 shows the model of the soil with 10460 solid elements, 14312 nodes and 10.640 degrees of freedom. To simulate the tower 4312 solid elements and 6932 nodes are used.

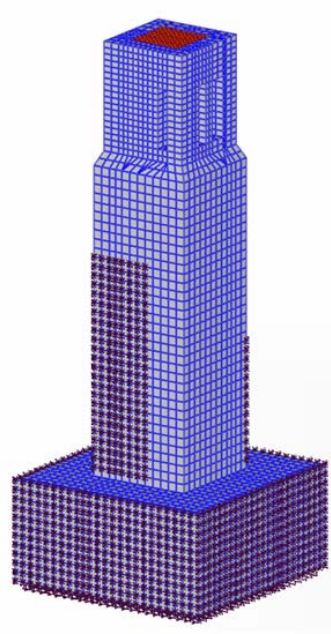

(a)

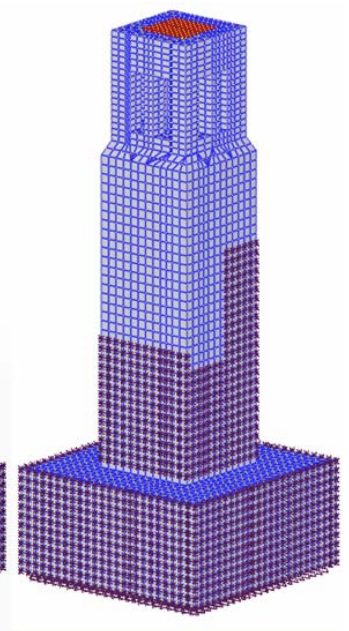

(b)
Figure 9. 3D FEM of the tower. Connections with chapel and church. (a) North and west façades (b)East and south façades

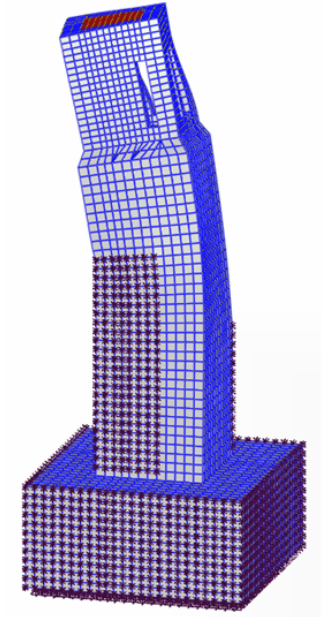

(a)

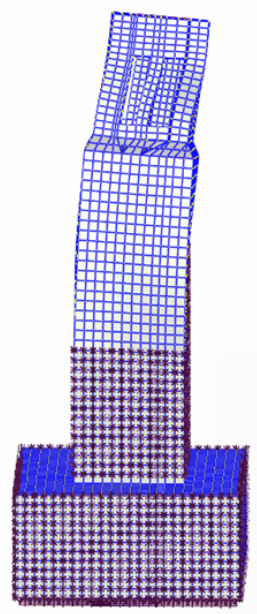

(b)

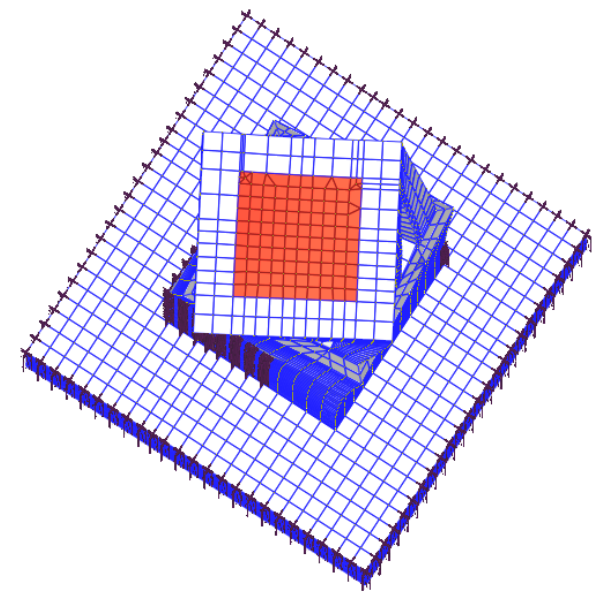

(c)

Figure 10. 3D FEM of the tower, (a) First mode (N-S). (b) Second mode (W-E) (c) Third mode. Torsion

After an iterative process an average elastic modulus for the structure of $1.500 \mathrm{~N} / \mathrm{mm} 2$ was obtained. For the basement an average elastic modulus of $200 \mathrm{~N} / \mathrm{mm} 2$ was obtained.
Table 3 shows the modal participating mass ratios of the structure. These mass modal ratios permit to identify the different modes.

Table 3: 3D model. Modal participating mass ratios

$\begin{array}{lll}\text { Mode } & \text { Natu } & \\ \text { classifica- } & \text { ral } & \text { Freq. } \\ \text { tion } & \text { Axis }\end{array}$

\begin{tabular}{|c|c|c|c|c|c|c|c|}
\hline & & \multicolumn{3}{|c|}{ Direction } & \multicolumn{3}{|c|}{ Rotation-axis } \\
\hline & & $\begin{array}{l}\mathrm{N}-\mathrm{S} \\
\%\end{array}$ & $\begin{array}{l}\text { E-W } \\
\%\end{array}$ & Axial & $\begin{array}{l}\mathrm{R}_{(\mathrm{N}-} \\
\mathrm{S}) \\
\% \\
\end{array}$ & $\begin{array}{l}\mathrm{R}_{(\mathrm{E}-} \\
\mathrm{W}) \\
\% \\
\end{array}$ & $\begin{array}{l}\mathrm{R}_{\mathrm{Z}} \\
\%\end{array}$ \\
\hline $\begin{array}{l}\text { Bending } \\
(\mathrm{N}-\mathrm{S})\end{array}$ & 2.17 & 30.1 & 6.5 & 0.0 & 12.7 & 61.1 & 1.6 \\
\hline $\begin{array}{l}\text { Bending } \\
(\mathrm{E}-\mathrm{W})\end{array}$ & 2.27 & 5.5 & 28.6 & 0.0 & 59.0 & 11.8 & 20.5 \\
\hline Torsion & 5.31 & 1.9 & 0.5 & 0.0 & 0.2 & 2.9 & 14.7 \\
\hline $\begin{array}{l}\text { Bending } \\
(\mathrm{N}-\mathrm{S})\end{array}$ & 6.70 & 7.2 & 5.3 & 4.2 & 5.1 & 6.5 & 1.8 \\
\hline Axial & 6.95 & 0.3 & 0.2 & 75.4 & 2.2 & 1.8 & 0.1 \\
\hline
\end{tabular}

Once the numerical model has been calibrated using the experimental results, the horizontal forces caused by the swinging bells are introduced in the model. From this analysis it has been obtained that the dynamic amplification factor is lower than 1 for all the bells, so no dynamic interaction is found between belltower and bells.

The first three modal frequencies of the horizontal force introduced by the swinging bells (Fig. 11) are separated more than 20\% (DIN 4078) from the first three natural frequencies of the structure, so the dynamic amplification factor due to this dynamic interaction is negligible in this case. (Fig. 12)

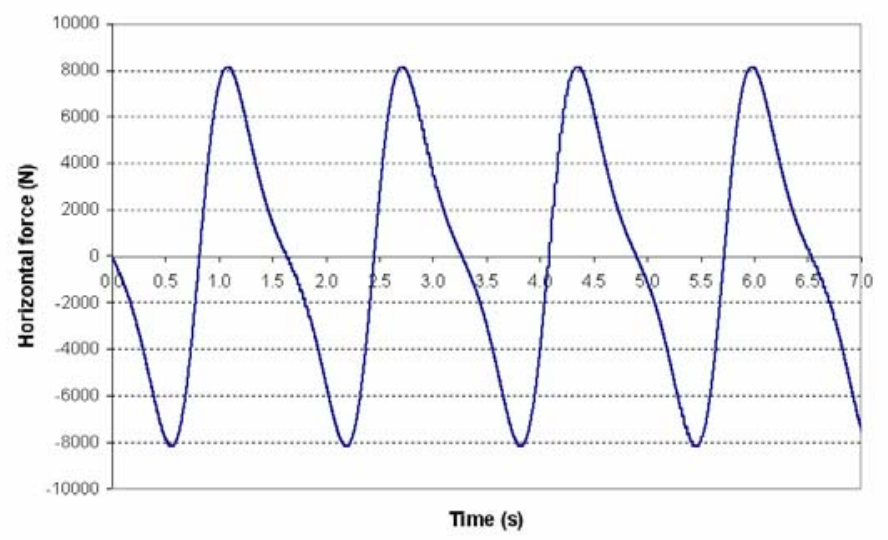

Figure 11. Horizontal force of bell number 5 


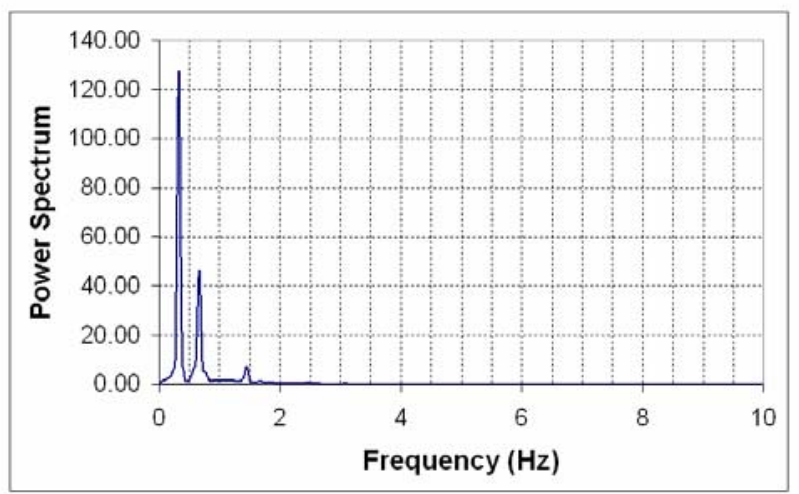

Figure 12. Power spectrum of horizontal force of bell number 5 .

\section{CONCLUSIONS}

A theoretical and experimental dynamic investigation of a historic masonry bell-tower is described in the paper. The following conclusions can be drawn from the study:

1. A simplified and low-cost method is described to evaluate the dynamic effect generated by the swing of bells on the bell tower.

2. With this non destructive and low-cost method five vibration modes were clearly identified within the frequency range $0-10 \mathrm{~Hz}$.

3. This gothic belltower has its first natural frequency higher than others presented in the scientific literature. This can be a singular aspect for this type of tower, because the ratio between wall thickness and slenderness can suggest a more rigid belltower than other architectural styles.

4. On this belfry, the swinging of bells swinging in the Spanish system causes no special or singular structural problems.

\section{ACKNOWLEDGEMENTS}

Authors want to thank the Generalitat Valenciana for funding this research through the granted project GV06/135.

\section{REFERENCES}

Bachmann, H. Ammann, W, Deischl, F., 1997. Vibration Problems in Structures: Practical Guidelines. Springer Verlag, Berlin, 50-55

Casolo, S., 1998. A three-dimensional model for vulnerability analysis of slender medieval masonry tower. Journal of Earthquake Engineering, Vol. 2, No. 4, 487-512.

Gentile, C., Saisi, A. (2007). Ambient vibration testing of historic masonry towers for structural identification and dam- age assessment, Construction and Building Materials Vol. 21, 1311-1321

Ivorra, S., Pallarés, F. (2006). Dynamic investigations on a masonry bell tower. Engineering Structures, Volume 28, Issue 5, April 2006, Pages 660-667.

NCSE-02. Norma de Construcción Sismorresistente Española. Parte General y Edificación (Spanish Standard). Ministerio de Fomento. 2002.

Heyman, J. \& Therefall, B.D. Inertia Forces due to Bell Ringing, International Journal of Mechanical Sciences, 18, 161-164, 1976

Ivorra, S., Llop F. Determinación de algunas características físicas de una campana. In Proc. of the XIV Congreso de Conservación y Restauración de Bienes Culturales. Valladolid, p. 891-900 2002[In Spainsh].

Ivorra, S. et alter (2005) Dynamic forces produced by swinging bells. Meccanica. International Journal of the the Italian Association of theoretical and applied mechanics. Ed. Kluwer Academic Press pub. Vol. 41- 1, 47 - 62, 2006

DIN 4178: “Glockentürme: Berechnung und Ausfhrung”; 1978

Schutz, K. G., 1994, Dynamische Beanspruchung von Glockentürmen. Bauingenieur 69, Springer-Verlag , 211-217

Selby, A. R. and Wilson J. M., 1997. Dynamic behaviour of masonry church bell towers, Worldwide Advances in Structural Concrete and Masonry. In: Proceedings of the CCMS Symposium, Chicago, ASCE, New York, 188-199.

Wilson, J.M., Selby A., 1993. Engineering a Cathedral, London, Thomas Telford Ltd., London, 77-100 